\title{
К ВОПРОСУ О ВЗАИМОДЕЙСТВИИ АСПИРАНТУРЫ И РЫНКА ТРУДА
}

\author{
Капшутарь М. А., Кандидат педагогических наук, доцент, заместитель начальника \\ Управления подготовки кадров высшей квалификаиии ФГБОУ ВО «Уральский \\ государственный медииинский университет», Екатеринбург, Россия, \\ ORCID ID: https://orcid.org/0000-0002-6662-7418
}

\section{DOI: https://doi.org/10.31435/rsglobal_conf/30082021/7646}

\begin{abstract}
The article analyzes the state of training of highly qualified personnel in graduate school from the point of view of analyzing the first results of the implementation of its new model. The problem of interaction of the education system, the labor market and the social behavior of young people is identified. The main trends in the field of postgraduate training are identified. The search for a new content of the educational program is associated with a modern interpretation of the understanding of the goals and results of the postgraduate program. The main labor markets for postgraduate graduates and the leading competencies demanded by these markets are considered. The problem of academic inbreeding in Russian universities is revealed. The study actualized the need to develop an educational program of postgraduate studies that is adequate to the new conditions of its work and takes into account the goals and needs of all participants in this process, implemented at the intersection of education, science and business.
\end{abstract}

Keywords: postgraduate studies, training of highly qualified personnel, postgraduate educational program, labor market, soft skills, competence, academic inbreeding.

Введение. Современное образование переживает период серьезных трансформаций. В частности, существенные изменения наблюдаются в национальных системах высшего образования, что связано с ускорением технологических и социальных ритмов, обусловливающих массовизацию и глобализацию высшего образования [1]. В связи с происходящей социальной трансформацией одной из основных задач образования становится обучение деятельности в условиях постоянных изменений. Люди вынуждены выстраивать свои жизненные стратегии, исходя из условий неопределенности, изменчивости и сложности происходящих процессов. Человек под влиянием постоянно изменяющихся обстоятельств вынужден становиться более мобильным, повышать свою конкурентоспособность, совершенствовать личностные и профессиональные навыки. Время «предъявляет новые требования к работнику: он должен получить в системе образования такую подготовку, чтобы быть способным совершенствовать и изменять свою квалификацию, следуя за переменами на рынке труда» [5, с. 56]. В сложившихся реалиях высшее образование должно отвечать требованиям гибкости, креативности и критичности, что в полной мере соответствует содержанию исследовательского образования. Именно поэтому интерес к аспирантскому образованию возрастает во всем мире.

Цель работы заключается в анализе состояния состояние подготовки кадров высшей квалификации в аспирантуре с позиции анализа первых результатов реализации ее новой модели. Показаны рынки труда для выпускников аспирантуры и необходимые для них компетенции. Актуализирована проблема разработки инновационных образовательных программ аспирантуры с целью повышения качества подготовки аспирантов.

Методы исследования связаны с анализом дискуссионных вопросов, обсуждаемых в научной среде, связанных с поиском нового понимания цели современной аспирантуры, определением eе основных функций. Проанализированы требования к содержанию образовательной программы аспирантуры. Показана актуальность разработки различных моделей реализации подготовки кадров высшей квалификации.

Результаты исследования. В качестве одной из важнейших проблем функционирования современного российского общества Д.Л. Константиновский [5], В.Е. Гимпельсон [2] и Г.А. Ключарев [4] отмечают проблему «взаимодействия системы образования, рынка труда и социального поведения молодежи». В частности, наблюдается структурное несоответствие системы высшего образования запросам рынка труда, перспективности и востребованности профессий. 
Успех развития любого общества связан с уровнем профессионализма во всех его сферах, особенно в образовании, развитие которого должно носить опережающий, инновационный характер. В новых условиях развития системы образования, связанных с усложнением социокультурной образовательной среды и принятием профессиональных стандартов, усиливается потребность в педагогических кадрах, способных решать задачи модернизации на всех уровнях образования. Аспирантура всегда рассматривалась как основной «поставщик» научных и педагогических кадров высшей квалификации.

На протяжении последних лет аспирантское образование в России переживает существенные трансформации. К основным трендам в этой области относятся: ориентация выпускников на широкий рынок интеллектуального труда, выходящий за рамки академической сферы, и структурированный формат подготовки аспирантов, нацеленный на развитие не только «жестких», но и «мягких» навыков.

Основным критерием качества подготовки аспирантов является соответствие требованиям основных заказчиков этого процесса. Для кого же готовит кадры современная аспирантура? Исследователи [6] составили рейтинг значимости рынков труда для выпускников аспирантуры. На первом месте в этом рейтинге - профессорско-преподавательский состав (ППС) вузов, на втором - научные сотрудники вузов и научно-исследовательских институтов, на третьем - руководители и менеджеры образовательных и научных организаций. Очевидно, что каждый из названных рынков труда требует сформированности значимых именно для него компетенций. В настоящее время компетентностный подход в подготовке аспирантов становится условием повышения эффективности деятельности аспирантуры.

Так, для рынка труда ППС наиболее значимыми являются компетенции в сфере применения методов и технологий образовательной деятельности; научно-исследовательские компетенции; компетенции в сфере саморазвития; этические и коммуникативные компетенции.

Для рынка труда научных сотрудников: научно-исследовательские компетенции; компетенции в сфере саморазвития; этические и коммуникативные, информационнотехнологические; компетенции в сфере экспертно-аналитической деятельности.

Для рынка труда руководителей и менеджеров образовательных и научных организащий: компетенции в сфере саморазвития; этические, правовые, проектные и организационно-управленческие; компетенции в сфере экономической и фандрайзинговой деятельности; коммуникативные компетенции [6].

Признавая приоритетность рынка профессорско-преподавательского состава вузов для выпускников аспирантуры, мы должны отметить крайне неблагоприятную ситуацию, складывающуюся в этом сегменте рынка труда в последние годы. Статистические исследования показывают неуклонное сокращение рабочих мест профессорскопреподавательского состава в вузах. Так, если в 2005/2006 учебном году численность ППС организаций высшего образования составляла 358,9 тыс. человек, то в 2018/2019 учебном году всего 236,1 тыс. человек [3]. Данное обстоятельство, с одной стороны, порождает проблему трудоустройства выпускников, а с другой повышает конкуренцию на рынке труда, особенно с учетом роста выпуска аспирантов по социально-гуманитарным специальностям и актуализирует проблему качества подготовки в аспирантуре.

Решение проблемы недостаточной ориентированности образовательных программ аспирантуры на требования значимых рынков труда возможно на путях разработки образовательных программ по профилям, которые не только соответствуют номенклатуре специальностей научных работников, но и учитывают целевую ориентацию на ключевые рынки труда и предъявляемые на них требования к компетенциям выпускников [6]. Мы разделяем точку зрения Б.И. Бедного о необходимости разносторонней образовательной программы аспирантской подготовки, направленной на развитие универсальных навыков выпускников аспирантуры вне зависимости от научного профиля их подготовки [8].

Еще одной значимой проблемой деятельности современной российской аспирантуры является так называемый академический инбридинг. Важным параметром, характеризующим трудоустройство выпускников аспирантур в вузах, является доля лиц, продолжающих трудовую деятельность в том же университете, в котором была пройдена программа аспирантуры. По данным исследователей [7], удельный вес таких выпускников равен 75\% и не претерпевает существенных изменений ни для отдельных дисциплинарных когорт 
выпускников, ни для отдельных типов вузов. Таким образом, в российских вузах доминирует модель воспроизводства собственного кадрового потенциала, что приводит к его консервации и, зачастую, негативно отражается на инновационном развитии высшей школы (этот вывод подтверждается более широкими исследованиями проблемы академического инбридинга) [9]. В России аспиранты вовлекаются в преподавание через кафедру и научного руководителя, к моменту окончания аспирантуры они уже глубоко укоренены в вузовской структуре и не видят альтернатив. А университет заинтересован в людях, уже получивших преподавательский опыт, интегрированных в социальную среду и проявляющих к ней лояльность. Можно говорить о том, что академический инбридинг положен в основу кадровой политики российских вузов.

Выводы. Таким образом, актуальной остается проблема разработки и внедрения инноваций в содержание подготовки, в учебно-методическое обеспечение образовательных программ, в систему аттестации (промежуточной и итоговой), а также в критерии и показатели эффективности научной работы аспиранта с целью ориентации аспирантской подготовки на значимые рынки труда. Образовательная программа аспирантуры должна ориентироваться, прежде всего, на запрос рынка труда и формировать соответствующие ему компетенции. Решение данной проблемы видится в ориентации на развитие универсальных навыков и компетенций. И в решении данной задачи важная роль принадлежит так называемым soft skills - «мягким» или «гибким» навыкам, которые рассматриваются как совокупность личностных характеристик, повышающих личную и социальную эффективность человека во всех сферах его деятельности.

Проблема разработки образовательной программы аспирантуры перейдет из области теоретической в сферу практики и может быть решена только тогда, когда будут определены цель и конечные результаты деятельности российской аспирантуры.

\section{ЛИТЕРАТУРА}

1. Альтбах Филипп Дж. Глобальные перспективы высшего образования. Москва: Издат. дом Высш. шк. экономики, 2018. $546 \mathrm{c}$.

2. Гимпельсон В. Е. Нужен ли российской экономике человеческий капитал? Десять сомнений // Вопросы экономики. 2016. № 10. С. 129-143.

3. Индикаторы образования: 2020: статистический сборник / Н.В.Бондаренко, Д. Р. Бородина, Л. М. Гохберг и др.; Нац. исслед. ун-т «Высшая школа экономики». М.: НИУ ВШЭ, 2020. 496 с.

4. Ключарев Г. А. «Разрыв» образования и рынка труда: мнения экспертов // Социологические исследования. 2015. № 11. С. 49-56.

5. Константиновский Д.Л. Образование, рынок труда и социальное поведение молодежи // Социологический журнал. 2014. № 3. С. 55-69.

6. Нечаев В.Д., Бродовская Е.В., Домбровская А.Ю., Карзубов Д.Н. Направления совершенствования программ аспирантуры по укрупненной группе специальностей и направлений «Образование и педагогические науки»: результаты экспертного опроса // Ценности и смыслы. 2016. № 5 (45). С. 10-32.

7. Рыбаков Н.В. Кадровое обеспечение науки и высшей школы в аспирантуре российских вузов: специальность 22.00 .04 «Социальная структура, социальные институты и процессы»: диссертация на соискание ученой степени кандидата социологических наук. Национальный исследовательский Нижегородский государственный университет им. Н. И. Лобачевского. Н.Новгород, 2020. 208 с.

8. Современная аспирантура и судьба института повышения квалификации: Круглый стол // Высшее образование в России. 2014. № 7. С. 71-85.

9. Sivak E., Yudkevich M. (2015) Academic Immobility and Inbreeding in Russian University Sector//M. Yudkevich, P. G. Altbach, L. E. Rumbley (eds) Academic Inbreeding and Mobility in Higher Education. Global Perspectives. Basingstoke, UK; New York: Palgrave Macmillan. P. 130-155. 